\title{
Report of chronic myeloid leukemia in chronic phase from Tata Memorial Hospital, Mumbai, 2002-2008
}

\section{Purvish Parikh}

Department of Medical Oncology, Tata Memorial Hospital, Mumbai, Maharashtra, India

\author{
Address for correspondence: \\ Dr. Purvish Parikh, \\ Indian Cooperative Oncology \\ Network, $1^{\text {st }}$ Floor, ICS \\ Rehabilitation Center, 74 Jerbai \\ Wadia Road, Parel Bhoiwada, Parel \\ East, Mumbai, Maharashtra, India. \\ E-mail: purvish1@gmail.com
}

\begin{abstract}
A B S T R A C T
Background: Chronic myeloid leukemia $(\mathrm{CML})$ is the commonest hematological malignancy in India. This manuscript is a single center analysis CML in chronic phase (CP). Materials and Methods: We did retrospective analysis of almost 1000 patients registered as chronic myeloid leukemia over a period of 6 years at Tata Memorial Hospital. Results: We found striking difference in cytogenetic response among patients presenting in late chronic phase (CP) compared with the patients in early $\mathrm{CP}$. The rate of complete cytogenetic response among patients in late CP was $60 \%$ while in early CP it was $80 \%$, which was statistically significant $(P=0.0001)$. The overall survival was $86 \%$, at a median follow-up of 51 months. Innovator glivec was taken by 671 patients among which complete cytogenetic response (CCyR) was seen in $72 \%$ whereas generic veenat was taken by 237 patients and CCyR was seen in $75 \%$ of them. Conclusion: Availability of imatinib has dramatically changed the outlook for CML in India. The response was identical for those treated with innovator brand of imatinib as compared to the generic brand. Hence quality generics provide a cost effective solution, which is particularly relevant in the current global scenario.
\end{abstract}

Key words: Chronic myeloid leukemia, chronic phase, Glivec, veenat

\section{INTRODUCTION}

Oncology centers like Tata Memorial Hospital (TMH) see a large number of patients with CML every year. We have actually witnessed the revolutionary change in the treatment of CML from parenteral injections to simple oral medication that translated into dramatically improved survival as well as quality-of-life for these patients. With the assistance of patient assistance programs thousands of lives have been saved without the need for expensive, difficult and toxic treatment with interferon, cytarabine or Bone marrow transplantation. The introduction of imatinib (IM) and other oral tyrosine kinase inhibitors (TKIs) have improved understanding of the disease and led to change in the parameters of documenting disease response. ${ }^{[1,2]}$ Complete blood counts are no longer accepted as response indicators

\begin{tabular}{|l|l|}
\hline \multicolumn{2}{|c|}{ Access this article online } \\
\hline Quick Response Code: & Website: \\
\hline & www.jmpo.org \\
\hline
\end{tabular}

by themselves; the value of cytogenetic and molecular response evaluation as well as mutation analysis is now well-established. ${ }^{[3,4]}$ In this retrospective analysis, we document the outcome in one of the largest group of CML patients treated in India.

\section{PATIENTS AND METHODS}

The data was collected retrospectively from year January 2002 to January 2008. The files and the electronic medical record of all patients diagnosed with CML at the hospital provided information pertaining to age, sex, date of diagnosis, address, phone number, blood counts, bone marrow reports, spleen size at diagnosis, cytogenetic and molecular reports brand and dose of IM, change in dose, any primary or secondary resistance; tolerability, the side-effects of IM and outcome. Data was also obtained from records of patient assistance programs.

\section{Definitions}

Standard definitions for chronic phase (CP), accelerated phase (AP) and blast crisis were taken. For CP CML, primary resistance/treatment failure to IM (400 mg daily) 
was defined as failure to achieve any one of the followingcomplete hematologic response (CHR) after 3 months, cytogenetic response after 6 months, major cytogenetic response after 12 months and complete cytogenetic response (CCyR) after 18 months of therapy. Secondary resistance was defined as any one of the following-loss of CCyR or rising white blood cell count to $>10 \times 10^{9} / \mathrm{L}$ on two occasions more than 4 weeks apart, progression to AP or progression to blast phases.

\section{Statistical analysis}

Event free survival (EFS) was defined as the time from initial diagnosis to primary/secondary resistance or death due to any cause. The statistical package for the social sciences system was used to analyses the data. The EFS and overall survival (OAS) probabilities were estimated using the Kaplan - Meier method and were compared using the $\log$ rank test. Differences among variables were evaluated using the $\chi^{2}$ test.

\section{RESULTS}

A total 972 patients of CML were registered between January 2002 and January 2008 with median age of 36 years (12-81 years). This included $730(75 \%)$ males and $242(25 \%)$ females, giving an M: F ratio of 3:1. Of these, 815 were evaluated at TMH at baseline. Their characteristics at diagnosis are shown in Table 1.

\section{Response pattern \\ CHR}

Documented CHR was available in 949 patients. Complete hematological response was documented in $937 / 949(98.7 \%)$ patients while $12(1.2 \%)$ patients showed primary resistance. Data was not available in 23 patients $(2.4 \%)$.

\section{CCyR}

Documented cytogenetic response data was available in 908/972 (93\%) patients. CCyR was seen in 699/908 (77\%), absent in 209 (21.5\%) and unknown in 64 (6.3\%). [Table 2].

CCyR in generic versus Gleevec

CCyR was analyzed as per the brand of the IM used. It was seen that Glivec was taken by 671 patients and CCyR was seen in $72 \%$ while veenat was taken by 237 patients and CCyR was seen in $75 \%$ of patients.

\section{CCy $R$ rate in patients taken with gaps}

It was found that irrespective of Brand, if there was more than 4 weeks gap of IM intake, the rate of CCyR was $57 \%$ and if it was less than 4 weeks the CCyR was $80 \%$.

\section{CCyR as per the era of treatment}

The data was analyzed by dividing the patient population into two eras, i.e., pre- and post-2003. Majority of patients presenting before 2003 were exposed to hydroxyurea or cytarabine or interferon before getting IM, as it was introduced in TMH on regular basis in late 2003. This population was considered as patients in late $\mathrm{CP}$ and after 2003 as in early CP. And as expected the rate of CCyR before 2003 was $60 \%$ and after 2003 was $80 \%$, which was statistically significant $(P=0.0001)$.

\begin{tabular}{|c|c|c|}
\hline \multicolumn{3}{|c|}{$\begin{array}{l}\text { Table 1: The characteristics at diagnosis } \\
\text { of } C M L \text { patients evaluated at baseline at } \\
\text { TMH }(N=815)\end{array}$} \\
\hline Characteristics & No. of patients & $\%$ of patients \\
\hline \multicolumn{3}{|l|}{ Hemoglobin } \\
\hline$<10 \mathrm{~g} / \mathrm{dl}$ & 390 & 47.8 \\
\hline$>10 \mathrm{~g} / \mathrm{dl}$ & 425 & 52.2 \\
\hline \multicolumn{3}{|c|}{ Total leucocyte count } \\
\hline$<50,000$ & 185 & 23 \\
\hline $50,000-100,000$ & 118 & 14.5 \\
\hline $100,001-200,000$ & 240 & 29.5 \\
\hline$>200,000$ & 272 & 33.4 \\
\hline \multicolumn{3}{|l|}{ Total platelet count } \\
\hline$<50,000$ & 8 & 1 \\
\hline $50,000-100,000$ & 21 & 2.6 \\
\hline $100,001-200,000$ & 115 & 14.1 \\
\hline$>200,000$ & 670 & 82.2 \\
\hline Missing data & 1 & 0.1 \\
\hline
\end{tabular}

$\mathrm{CML}$ - Chronic myeloid leukemia; TMH - Tata memorial hospital

Table 2: CCyR with respect to various categories

\begin{tabular}{|c|c|c|c|}
\hline Category & $\begin{array}{l}\text { No. of } \\
\text { patients }\end{array}$ & $\begin{array}{l}\text { CCyR } \\
\%\end{array}$ & $P$ value \\
\hline \multicolumn{4}{|l|}{ Generic versus Innovator Imatinib } \\
\hline $\begin{array}{l}\text { Innovator Imatinib (Gleevec, } \\
\text { Novartis) }\end{array}$ & 671 & 72 & $P=0.058$ \\
\hline $\begin{array}{l}\text { Generic Imatinib (Veenat; } \\
\text { Natco) }\end{array}$ & 237 & 75 & \\
\hline \multicolumn{4}{|l|}{$\begin{array}{l}\text { Presence or absence of } \\
\text { extrachromosomal changes }\end{array}$} \\
\hline Present & $\begin{array}{l}250 \text { (112 had } \\
9 q \text { deletion) }\end{array}$ & 72 & $P=0.024$ \\
\hline Absent & 658 & 79 & \\
\hline \multicolumn{4}{|l|}{$\begin{array}{l}\text { Presence or absence of gap more } \\
\text { than } 4 \text { weeks }\end{array}$} \\
\hline Present & 99 & 57 & $P=0.0001$ \\
\hline Absent & 809 & 80 & \\
\hline \multicolumn{4}{|l|}{$\begin{array}{l}\text { In different eras (largely depicting } \\
\text { time to start IM) }\end{array}$} \\
\hline $\begin{array}{l}\text { Before and in } 2003 \text { (late chronic } \\
\text { phase) }\end{array}$ & & 60 & $P=0.0001$ \\
\hline $\begin{array}{l}\text { After and in } 2004 \text { (early chronic } \\
\text { phase) }\end{array}$ & & 81 & \\
\hline
\end{tabular}




\begin{tabular}{lccccccc}
\hline \multicolumn{7}{l}{ Table 3: Comparison of response as } & per Sokal risk group and brand of IM \\
\hline Sokal risk category & $\begin{array}{c}\text { All patients } \\
\text { (out of 451) (\%) }\end{array}$ & CCyR (\%) & Patients receiving Glivec & CCyR (\%) & $\begin{array}{c}\text { Patients receiving } \\
\text { veenat+other brands }\end{array}$ & CCyR (\%) & P value \\
Low risk & $152(34)$ & $116(76.3)$ & 117 & $90(76.3)$ & $21+14$ & $15(71)+11(85)$ & NS \\
Intermediate risk & $186(41)$ & $139(74.7)$ & 141 & $104(73.8)$ & $31+14$ & $25(81)+10(71)$ & NS \\
High risk & $113(25)$ & $83(73.4)$ & 75 & $58(77 \cdot 3)$ & $33+4$ & $23(70)+2(50)$ & NS \\
\hline
\end{tabular}

CCyR - Complete cytogenetic response; NS - Not significant; IM - Imatinib

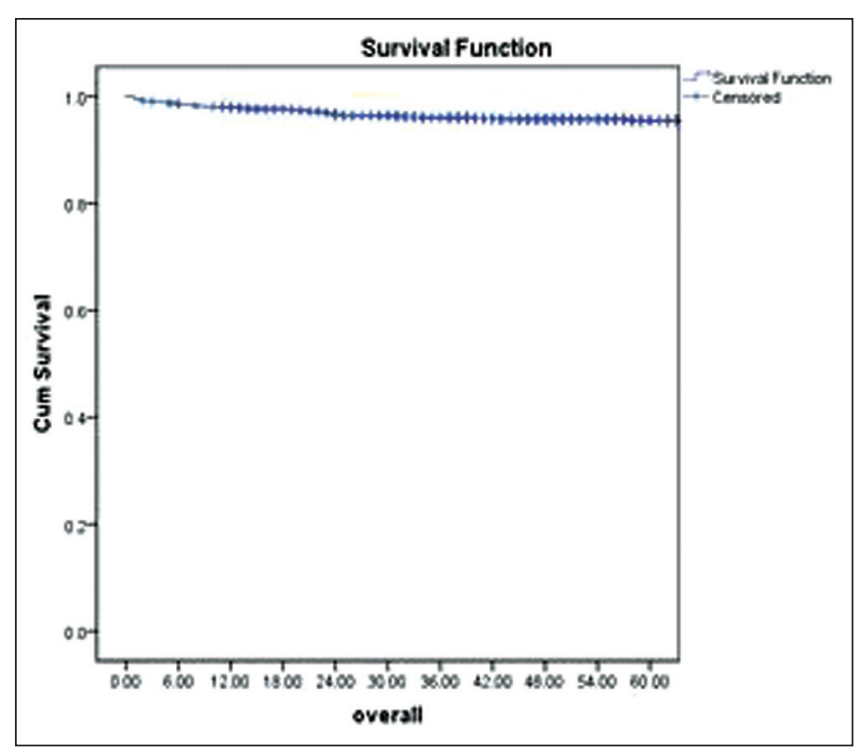

Figure 1: The overall survival of the patients diagnosed with chronic myeloid leukemia

\section{CCyR as per risk category and brand of IM}

Table 3 shows the rate of response among various Sokal risk group categories. The CCyR was similar in all the three risk groups. The brand of IM used also did not seem to influence this outcome parameter.

\section{OAS}

The OAS for whole population with median follow of 51 months was $86 \%$.

At median follow-up of 51 months, the projected 5 year OAS for all patients was $86 \%$ [Figure 1]. The various events in population of 972 patients were as follows: In remission was 510 (53\%), documented resistance or relapse was seen in $372(38 \%)$, death occurred in 40 (4.1\%), IM was stopped in $3(0.3 \%)$ and lost to follow-up were $47(4.8 \%)$ patients.

\section{DISCUSSION}

Targeted therapy in the form of TKIs has completely changed the management and the outcome of CML. In this study, we made the comparisons between the groups like brand of IM, presence or absence of clonal evolution; time to start IM, continuity in taking IM. As this is retrospective data, it has its limitations. Nevertheless, it gives us few important points to ponder. Foremost, post-IM the OAS of our population is comparable with western population. We had OAS survival of $86 \%$ at 5 years, which was comparable with the landmark study, the international randomized study of interferon versus STI571 (IRIS) trial showing $89 \%$ OAS at 5 years ${ }^{[5]}$ Second, our data showed that patients presenting in early CP do better when compared to patients in late CP. Again this finding is well documented in the literature. In a phase II trial by Gambacorti et al., they found patients in late CP had CCyR of $55 \%$ compared to $87 \%$ in early CP, as reported in IRIS trial. ${ }^{\left[{ }^{[6]}\right.}$ Third, CCyR also depends on the continuation of IM intake. This data emphasizes that to have best results, it is important to minimize the gaps in IM intake and this can be achieved only by aggressive patient counseling and by optimizing the drug dosage on regular basis. The importance of IM adherence has been well-documented in ADAGIO study and data reconfirms it. ${ }^{[7]}$ Fourth, the most important conclusion we can make in this study is that there is not much difference in the outcome of patients taking different brands of IM and generic can be used where original drug is not available to the patient.

\section{REFERENCES}

1. Baccarani M, Saglio G, Goldman J, Hochhaus A, Simonsson $\mathrm{B}$, Appelbaum $\mathrm{F}$, et al. Evolving concepts in the management of chronic myeloid leukemia: Recommendations from an expert panel on behalf of the European LeukemiaNet. Blood 2006;108:1809-20.

2. Kantarjian HM, Cortes JE, O'Brien S, Giles F, Garcia-Manero G, Faderl S, et al. Imatinib mesylate therapy in newly diagnosed patients with Philadelphia chromosome-positive chronic myelogenous leukemia: High incidence of early complete and major cytogenetic responses. Blood 2003;101:97-100.

3. Wang L, Pearson K, Pillitteri L, Ferguson JE, Clark RE. Serial monitoring of BCR-ABL by peripheral blood real-time polymerase chain reaction predicts the marrow cytogenetic response to imatinib mesylate in chronic myeloid leukaemia. $\mathrm{Br}$ J Haematol 2002;118:771-7.

4. Kantarjian H, Sawyers C, Hochhaus A, Guilhot F, Schiffer C, Gambacorti-Passerini $\mathrm{C}$, et al. Hematologic and cytogenetic responses to imatinib mesylate in chronic myelogenous leukemia. N Engl J Med 2002;346:645-52.

5. O'Brien SG, Guilhot F, Goldman JM, Hochhaus A, Hughes TP, Radich JP, et al. International randomized study of interferon versus STI571 (IRIS) 7-year followup: Sustained survival, low rate of transformation and 
increased rate of major molecular response (MMR) in patients (pts) with newly diagnosed chronic myeloid leukemia in chronic phase (CML-CP) treated with imatinib (IM). Blood 2008;112:76.

6. Gambacorti C, Talpaz M, Sawyers C, Druker BJ, Hochhaus A, Schiffer CA, et al. Five year follow up results of a phase II trial in patients with late chronic phase (L-CP) chronic myeloid leukemia (CML) treated with imatinib who are refractory/intolerant of interferon-alpha [abstract]. Blood 2005; 106:1089.
7. Noens $L$, van Lierde MA, De Bock $R$, Verhoef $G$, Zachée $P$, Berneman Z, et al. Prevalence, determinants, and outcomes of nonadherence to imatinib therapy in patients with chronic myeloid leukemia: The ADAGIO study. Blood 2009;113:5401-11.

How to cite this article: Parikh P. Report of chronic myeloid leukemia in chronic phase from Tata Memorial Hospital, Mumbai, 2002-2008. Indian J Med Paediatr Oncol 2013;34:164-7.

Source of Support: Nil. Conflict of Interest: None declared.

\section{Author Help: Online submission of the manuscripts}

Articles can be submitted online from http://www.journalonweb.com. For online submission, the articles should be prepared in two files (first page file and article file). Images should be submitted separately.

1) First Page File:

Prepare the title page, covering letter, acknowledgement etc. using a word processor program. All information related to your identity should be included here. Use text/rtt/doc/pdf files. Do not zip the files.

2) Article File:

The main text of the article, beginning with the Abstract to References (including tables) should be in this file. Do not include any information (such as acknowledgement, your names in page headers etc.) in this file. Use text/rtt/doc/pdf files. Do not zip the files. Limit the file size to $1 \mathrm{MB}$. Do not incorporate images in the file. If file size is large, graphs can be submitted separately as images, without their being incorporated in the article file. This will reduce the size of the file.

3) Images:

Submit good quality color images. Each image should be less than $4096 \mathrm{~kb}(4 \mathrm{MB})$ in size. The size of the image can be reduced by decreasing the actual height and width of the images (keep up to about 6 inches and up to about $1800 \times 1200$ pixels). JPEG is the most suitable file format. The image quality should be good enough to judge the scientific value of the image. For the purpose of printing, always retain a good quality, high resolution image. This high resolution image should be sent to the editorial office at the time of sending a revised article.

4) Legends:

Legends for the figures/images should be included at the end of the article file. 